\title{
RESISTENCIAS PARCIALES Y ABIERTAS: CON- FLICTO DE CLASES EN EL MEDIO RURAL GALLEGO (SIGLOS XIII Y XV)
}

\author{
José Antonio LÓPEZ SABATEL \\ Universidad de Santiago
}

\begin{abstract}
RESUMEN: Este artículo pretende un acercamiento al medio rural gallego medieval como marco generador del conflicto de clases. Antagonismo social que encuentra un nexo de unión entre las resistencias campesinas precedentes, y la actitud transgresora del régimen señorial llevada a término por las hermandades rurales en el seno del levantamiento irmandiño. Actitud que menoscabaría la homogeneidad de intereses subyacentes en el seno del citado movimiento social, divergiendo del mismo dos líneas de actuación enfrentadas: la legalista, y relativa a los rectores de las hermandades ciudadanas y la antifeudal e inherente a los cambios sociales propuestos por la masa campesina.
\end{abstract}

PALABRAS CLAVE: Campesinado, Régimen señorial, Conflicto de clases, Resistencias campesinas, Hermandades, Movimiento irmandiño.

ABSTRACT: This article intends to be an approximation to the rural Galician environment in middle ages, as generating frame of the class conflict. Social antagonism, that finds a link of union between the previous rural resistance, and the transgressing attitude against the lordly regime carried out by the rural brotherhoods in the irmandiño uprising. Attitude that would diminish the homogeneity of underlying interests in the mentioned social movement, two confronted lines of action diverging from the same one: the legalistic one, and relating to the urban brotherhood's heads and the anti-feudal one and inherent in the social changes proposed by the rural mass.

KEYWORDS: Peasantry, Lordly regime, Class conflict, Rural resistances, Brotherhoods, Irmandiño movement.

No hay duda que el movimiento irmandiño, desde mediados del siglo XIX, fue objeto de interés por parte de una historiografía de corte galleguista, que pronto se sintió con predisposición en convertirlo en un hecho histórico de carácter diferencial, bajo la premisa de reafirmar la intrínseca identidad gallega frente al resto de España y de Europa ${ }^{1}$. No es de extrañar, en consecuencia, que con el

${ }^{1}$ Siguiendo esta línea de pensamiento Benito Vicetto escribiría: “ La historia de Galicia es, por el contrario la historia del primer pueblo de Europa, pues desde sus últimos ventisqueros surgió la raza 
devenir de los años, este fenómeno se haya paulatinamente transformado en un mito nacionalista al igual que ha sucedido con el celtismo, los avatares de monte Medulio o la figura de Prisciliano entre otros².

Por otro lado, y también bajo el manto de este Rexurdimento gallego de segunda mitad del siglo XIX y de acorde con los postulados del historicismo romántico impregnado de su consabida ideología liberal, se colocan los primeros cimientos de una línea explicativa que perduraría hasta nuestros días, en la que el antagonismo social es uno de sus rasgos definitorios más relevantes ${ }^{3}$.

Este antagonismo social, transmutado en la premisa de lucha de clases, como es bien sabido, bajo el manto de la historiografía marxista, se constituiría como motor de la historia, esto es, el arquetipo vertebrador de la evolución de los diferentes estadios históricos. Epítome que no hizo más que fomentar la negación de dicho concepto por aquellos que no compartieron tal modelo gnoseológico, y la receptividad más allá de lo que el sentido común demandaba de los que si lo hicieron ${ }^{4}$.

No hay que olvidar, que el concepto de clase social y su protagonismo dialéctico en el desarrollo del capitalismo, está sujeto a eterna disputa en el marco de la sociología entre neomarxistas y neoweberianos. Estos últimos, siguiendo los postulados del fundador de esta corriente ideológica, desarrollada a raíz de sus tesis sobre la relación entre la ética protestante y el espíritu del capitalismo, colocan al individualismo en contraposición con el factor social y colectivo de clase subyacente en las proposiciones marxistas, como patrón generador de la racionalidad capitalista. Es más, las clases como meras formas de estratificación social, no constituirían un grupo consciente de su propio status más allá de ciertos

más dominante y en sus últimos ventisqueros se consolidó la doctrina social más humanamente divina”. VicetTo, B. (1873). Historia de Galicia, Vol. I, O Ferrol: Ed. Nicasio Taxonera, p. 8.

2 BARros, C. (1994). "Mitos de la historiografía galleguista". Manuscrits.Revista d'historia moderna, 12, pp. 245-266.

${ }^{3}$ Así según Benito Vicetto el levantamiento irmandiño responde a una "lucha... de siervos y señores... del trabajo contra la ociosidad hereditaria, de la democracia, en fin contra la aristocracia”. VICETTO, B. Historia de, Vol. XIII, p. 94.

Afirma también Murguía que "es pues evidente... que la mayor parte de las insurrecciones populares de Galicia durante este periodo no tuvieron otro carácter que el de una lucha entablada entre... el señor y el vasallo”. Murguía, M. (1861). "De las guerras de Galicia en el siglo XV y de su verdadero carácter”. Galicia. Revista Universal de este Reino, 1, pp. 118-149.

${ }^{4}$ Fossier, R. (1996). La sociedad medieval. Barcelona: Crítica, p. 454. 
condicionantes derivados de la vida material ${ }^{5}$. Incluso una piedra angular de toda formulación marxista, como la lucha de clases, a su vez, aunque obviamente sujeta a distintos parámetros, fue el núcleo de un debate interno en el seno del mismo materialismo histórico, a raíz de la publicación del artículo titulado "Estructura de clases agrarias y desarrollo económico en la Europa preindustrial” en la revista Past and Present ${ }^{6}$. Su autor, Robert Brenner, suscitó la controversia al afirmar que sería la lucha de clases, por encima de cualquier otra consideración, la causa determinante de la crisis bajomedieval y de una transformación estructural, punto de partida a su vez, del desarrollo del capitalismo moderno. Sus detractores, por el contrario, darían la preeminencia como motor de la evolución histórica, a la pugna subyacente entre las fuerzas productivas y las relaciones de producción ${ }^{7}$.

\section{CLASES ANTAGÓNICAS, VÍCTIMAS COMUNES}

Todo lo referido hasta ahora sólo pretende exponer un pequeño pero significativo boceto de la controversia suscitada por términos tales como clase social o lucha de clases, al formularse los mismos de acorde con diferentes y subjetivos análisis hermenéuticos, elaborados con el fin de facilitar la comprensión de la esencia en sí misma, las líneas de actuación y las motivaciones, de los distintos grupos de individuos en el tránsito de la sociedad precapitalista hacia una nueva forma de desarrollo histórico. Y es que teóricamente, en la sociedad feudal, estos grupos no estarían organizados por clases sociales, sino según órdenes estamentales preestablecidos y estáticos. Teóricamente, puesto que como es bien conocido, tal ordenación no dejaba de ser una enunciación ideológica-especulativa de poder elaborada precisamente por aquellos que se situaron en la cúspide de la misma, los doctores de la iglesia. Si la naturaleza de dicho modelo fue teórica, los fines del mismo serían bien pragmáticos. Así, en sus cimientos, se asentaría no sólo la inmunidad fiscal de los estados superiores, sino que asimismo, la iglesia como única intermediaria de Dios en la tierra, se garantizaría parte de las rentas campesinas cedidas en busca de una intercesión divina que asegurase a sus donantes la salvación de sus almas ${ }^{8}$. De manera que no es de extrañar que en la documentación privada del orensano monasterio de Santa María de Oseira, se

\footnotetext{
${ }^{5}$ WeBer, M. (1992). La ética protestante y el espíritu del capitalismo. Barcelona: Península, pp. 41-80

Ibidem. (1992). Economía y sociedad. Esbozo de sociología comprensiva. México. D.F.: Fondo de Cultura Económica, pp. 242-248.

${ }^{6} \mathrm{~N}^{\mathrm{o}} 70$ de esta revista (febrero de 1976).

${ }^{7}$ Aston, T.H. y Philpin, C.H.E. (1988). El debate Brenner, Barcelona: Crítica.

8 Duby, G. (1999). Guerreros y campesinos. Desarrollo inicial de la economía europea (5001200). Madrid: Siglo XXI, pp. 208-209.
} 
recojan entre 1137 y 1310 ciento veintitrés donaciones de las cuales la gran mayoría son estimuladas bajo la expresión "pro anima"9.

En consecuencia, y parafraseando a Pierre Bonnassie "Ello no significa que la sociedad se hubiese partido bruscamente en tres: la ideología tripartita no es de ningún modo creíble como descripción de lo real. Como toda ideología, era antes que nada un fantasma. Un sueño, una representación mental, el espectáculo que los

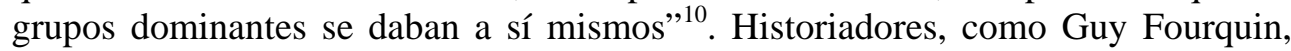
sustentaron la tesis que abogaba por la validez de esta representación mental nacida de los grupos rectores de la sociedad para el conjunto de la misma. Así, este modelo jerárquico se erigiría como estructura de pensamiento generalizado y en consecuencia, la sociedad medieval se configuraría en órdenes, siendo del todo erróneo hablar de una sociedad clasista ${ }^{11}$. Sin embargo, como apunta Fossier, si se entienden estos estados como capas sociales, cuya unidad viene dada por la participación de sus miembros del mismo estatuto económico y jurídico, resulta incuestionable el concepto de clase a lo largo de la Edad Media ${ }^{12}$. Opinión que comparte Julio Valdeón, cuando afirma que la ordenación trifuncional clásica medieval no hace sino disfrazar una latente división de clases ${ }^{13}$. Por otro lado, es notoria y común la utilización en su lenguaje, por parte de la historiografía medieval, de términos como "clase” y "lucha de clases” en su labor de análisis de los diferentes movimientos sociales.

Por lo que respecta a este antagonismo social, relacionado con la Santa Hermandad gallega, transcendió el umbral del ostracismo localista, al que se vio condenado durante décadas el tumultuoso siglo XV gallego, ocupando el lugar que le corresponde en el análisis de los movimientos sociales de la historiografía castellana.

De este modo, el levantamiento irmandiño no tardaría en recibir epítetos como el de "los comienzos de una lucha de clases"14, e incluso "la más importante

9 Romaní, M. (1989). El monasterio de Santa María de Oseira (Ourense). Estudio histórico (1137-1310). Santiago de Compostela: Universidad de Santiago, p. 36.

${ }^{10}$ Bonnassie, P. (1999). Vocabulario básico de la historia medieval. Barcelona: Crítica, p. 165.

${ }^{11}$ Fourquin, G. (1972). Les soulèvements populaires au Moyen-Age, Paris: P.U.F., p. 52.

12 Fossier, R. La sociedad, p. 454.

13 VALDEÓn, J. (1975). “Tensiones sociales en los siglos XIV y XV”. Actas de las I jornadas de metodología aplicada de las ciencias históricas, Vol. II (Historia medieval).Vigo: Universidad de Santiago, pp. 257-279.

14 García De Cortázar, J. A. (1973). La época medieval. Madrid: Alianza universidad, pp. 437444. 
revuelta antifeudal que tuvo lugar en tierras de la corona de Castilla en la Baja Edad Media" ${ }^{15}$.

Las fuentes documentales siempre recurrentes, a la hora de fundamentar cualquier investigación relativa al movimiento irmandiño ${ }^{16}$, son susceptibles de ofrecer una extensa información correspondiente tanto al desarrollo como a la naturaleza de este movimiento. Aspectos como la formación, organización, composición social y expansión de la revuelta, se encuentran bien definidos a lo largo de la documentación.

En relación al desencadenante que en primera instancia fundamenta el levantamiento, nunca se ha ignorado la posición de primer orden que ocupa la gran variedad de atropellos y desmanes que tiene que sufrir gran parte de la población por parte de los señores. De hecho, es común otorgar a una puntual expresión de agravio señorial, el papel de detonante primigenio en los movimientos populares más destacados de la baja Edad Media europea ${ }^{17}$. En Galicia, el problema del bandidaje relacionado con la imagen del caballero salteador, también llamado golfín, llegó a ser alarmante hacia la segunda mitad del siglo $\mathrm{XIV}^{18}$. La preocupación por esta cuestión se encuentra en la querella presentada en 1357 por el procurador del monasterio de Santa María de Oseira ante el adelantado mayor de Galicia, por causa de la fortaleza que Alfonso Suárez, escudero de Deza, está levantando en un coto perteneciente a dicho cenobio. El procurador conmina al adelantado a hacer justicia porque

Alguus en esta terra deGallisa hu nos vivemos non temendo el rey nen a sua justiça feseron e fasen moyto mal a o moesteiro d'Osseira por roubos, forças e queimas e morte d'omees d'orden et d'outros seus lavradores ${ }^{19}$.

${ }^{15}$ VAldEÓN, J. (1979). Los conflictos sociales en el reino de Castilla en los siglos XIV y XV. Madrid: Siglo XXI, p. 192.

16 RodrígueZ, Á. (1975). "Fuentes para el estudio del movimiento hermandino”. Actas de las I jornadas de metodología aplicada de las ciencias históricas, Vol. II (Historia medieval).Vigo: Universidad de Santiago, pp. 301-311.

17 Hilton, R. (1984). Siervos liberados. Los movimientos campesinos medievales y el levantamiento inglés de 1381. Madrid: Siglo XXI, p. 49 y pp. 149-180.

18 García, J. (1999). Galicia na Baixa Idade Media. Igrexa, señorío e nobreza. A Coruña: Toxosoutos, p. 38.

19 ACOrense. Pergaminos monacales, no 2705. Ed. Romaní, M. et alii. (1993). Colección Diplomática do mosteiro cisterciense de Sta. María de Oseira (Ourense) 1310-1399, Vol. III. Santiago de Compostela: Tórculo Edicións, p. 270. 
Carlos Barros en su excelente estudio sobre la mentalidad justiciera irmandiña ha clasificado los delitos denunciados en el Pleito Tabera-Fonseca y en concejo de Orense según su tipología. El resultado es el que sigue: cincuenta y dos robos, treinta y una prisiones, veintiún rescates, quince heridas, catorce amenazas, trece destrucciones, diez muertes, nueve apropiaciones por la fuerza de rentas, seis tormentos, cinco injurias, cuatro violaciones, una toma de prenda y una ruptura de tregua. Con respecto a la clasificación social de las víctimas en el reino de Galicia, según el pleito Tabera-Fonseca, la relación porcentual es la siguiente: labradores $39 \%$; caminantes 26\%; pescadores $13 \%$; mujeres $8,6 \%$; caballeros $4,3 \%$; escuderos $4,3 \%$; oficiales $4,3 \%^{20}$.

Se observa que el campesinado es el sector social cuantitativamente más agredido. Una conclusión que no difiere mucho del resultado de diversos análisis relativos a la confrontación social tanto en el ámbito castellano-leonés ${ }^{21}$ y aragonés $^{22}$ como en el catalán ${ }^{23}$ y vasco ${ }^{24}$. El medio rural se articula como el terreno propicio para el desarrollo de las tensiones sociales. Si bien en el espacio urbano, el conflicto se tiñe de intereses meramente políticos, al encaminarse a la consecución de mayores cuotas de poder que garantizasen y en otros casos consolidasen, la fortuna personal de ciertos colectivos de la ciudadanía, en el campo, por el contrario, el interés por limitar o abolir rentas y prestaciones arbitrarias y excesivas, confiere a las resistencias y revueltas campesinas el carácter de una verdadera lucha por la vida ${ }^{25}$.

La relación causal entre las fechorías cometidas por los caballeros, y el derrocamiento de las fortalezas, reproducidas en el pensamiento de los damnificados como iconos de la violencia señorial, es una constante en las

${ }^{20}$ Barros, C. (1990). Mentalidad justiciera de los irmandiños, siglo XV. Madrid: Siglo XXI, pp. 129 y $163-166$.

${ }^{21}$ Moreta, S. (1978). Malhechores-Feudales. Violencia, antagonismos y alianzas de clases en Castilla, siglos XIII-XIV. Madrid: Cátedra, pp. 55 y 67.

22 SARASA, E. (1981). Sociedad y conflictos sociales en Aragón. Siglos XIII y XV. Estructuras de poder y conflictos de clase. Madrid: Siglo XXI, pp. 101 y 106.

23 CuAdrada, C. (1988). El Maresme medieval: Hàbitat, Economia i Societat, segles X-XIV. Mataró: Rafael Dalmau Ed., pp. 295-296.

${ }^{24}$ Los campesinos querrán formar parte de la jurisdicción de la villa de Mondragón “...porque vivimos en servidumbre escura e muy desaguisada con los males e dapnos e furtos e robos e fuerzas e desaguisados que recibimos de los ricos hombres e caballeros e escuderos que viven e entran en la dicha comarca...” en Díaz De DuranA, J. R. (1999). "Conflictos sociales en el mundo rural guipuzcoano a fines de la Edad Media: Los campesinos protagonistas de la resistencia antiseñorial”. Hispania, 202, pp. 433-455.

${ }^{25}$ Le Goff, J. (1999). La civilización del occidente medieval. Barcelona: Paidós, p. 269. 
declaraciones del pleito Tabera-Fonseca. A fin de cuentas, estas fortificaciones se representan a sí mismas como nidos de bandas de delincuentes amparados por los diferentes señores locales

...este dicho testigo dize que hera la fama publica que los dichos ladrones y malfechores se acogian con los caballeros y señores que hestonçes abia en la dicha tierra y en sus fortalezas y desde ellas salian a fazer los dichos males y robos a los dichos labradores y gentes comunes del dicho Reino... ${ }^{26}$

Estamos en presencia de un auténtico bandolerismo nobiliario afincado, no de manera exclusiva en tierras gallegas, como se refleja en diferentes actas de cortes castellano-leonesas a lo largo del reinado de Enrique IV. Así, en las cortes de Toledo de 1462, se denuncia la protección que dispensan los señores a los malhechores (que no son sino sus agentes), cobijándolos tras los muros de sus castillos, con el fin de lograr la impunidad de sus crímenes. También se deja constancia en las cortes de Santa María de Nieva de 1473, que son estas fortalezas el foco de irradiación de todos los daños provocados, y en las de Ocaña de 1469, que estos caballeros, amparados en su poder, echan a las gentes de sus pueblos y les toman sus bienes. ${ }^{27}$ La figura delictiva del noble como depredador, y cabeza visible de bandas de malhechores respondiendo a la terminología inglesa de "furcollar crime”, también sería común fuera de la península durante la segunda mitad del siglo $\mathrm{XV}^{28}$.

En el seno del medio rural, no sólo fue el labrador víctima propiciatoria de los atropellos señoriales. Los señoríos monásticos sufrieron también sus desmanes, como muestra la querella interpuesta en 1386 por el monasterio de Montederramo recogida por Carlos Barros

Diego Gómez, sin Dios e sin razón e siin derecho, en vituperio e deshonra mía y del dicho mi moasterio y de los dichos monxes... con otros homes armados, de pie e de cavallo, e comvatió al dicho monasterio e quebrantó las puertas al dicho moasterio, fasta que el e los dichos malhechores y feriron a un mi mayordomo... denostrando a mi el dicho abbad e monxes de muchos

${ }^{26}$ RodRíGUEZ, Á. (1984). Las fortalezas de la mitra compostelana y los “irmandiños”, Vol. II. A Coruña: Fundación Pedro Barrié de la Maza, p. 442.

${ }^{27}$ LÓPEZ, Carmen. (1978). “Conflictividad social y pobreza en la Edad Media según las actas de las cortes castellano-leonesas”. Hispania, 140, pp.475-549.

28 Mendoza, J. M. (1993). "La delincuencia a fines de la Edad Media. Un balance historiográfico”. Historia, Instituciones, Documentos, 20, pp. 231-259. 
males e feos denuestros... E poseran arrobo el dicho moasterio, e tomaron vino e pan e gallinas e ansares e rropas e otros bees ${ }^{29}$

Sin embargo, la fórmula más frecuente de encubrir de manera nada solapada el pillaje se encontraría en la encomienda. Figura jurídica que derivaría a lo largo de los siglos XIV y XV en patente para todo tipo de violencias y rapiñas ${ }^{30}$. Las demandas de amparo presentadas ante el rey por los abades y priores, así como las sentencias reales propicias a las mismas, son una constante en la documentación real y monacal. A causa de esta magnitud documental, merecedora de ser tratada en un estudio mucho más amplio, aquí, sólo me referiré a las actuaciones de un único encomendero, el conde de Lemos, don Pedro y sus agentes, como muestra de un proceder bastante generalizado en la nobleza laica. Si en 1295 el rey Sancho IV exime al monasterio de San Esteban de Ribas de Sil del pago de pedidos y yantares, ordenando además que la encomienda de dicho cenobio recaiga en su abad ya que ...el abbad e el convento del monasterio de Sant Estevan de Riba de Sil me enbiaron mostrar en como ellos son muchos afincados e pobres por pedidos e por la mi jantar...e por muchos otros afincamientos e males que les fazen fijosdalgo e otros onbres... ${ }^{31}$, casi un siglo después en 1380 el expolio, lejos de languidecer persiste. Es en este año cuando un nuevo rey, Juan I, atiende la querella presentada por el abad del mismo monasterio, en relación con un otro abuso existente so pretexto de encomienda. La parte demandada es don Pedro Enríquez, conde de Lemos y pertiguero mayor de la tierra de Santiago, y su vasallo Juan Pérez de Novoa. La acusación diáfana. El conde contra la voluntad del abad, se había hecho con la encomienda de un coto y veinte casares en tierra de Lemos, embolsándose veinte moyos de pan y vino por los mismos. Además, exigía pedidos de pan y dineros a los vasallos del monasterio, obligándolos a prestar servicio en la construcción de una cerca en Monforte. Por su parte, Juan Pérez de Novoa, encomendero del monasterio recaudaba por "protección” cien maravedíes anuales además de todas las rentas de seis casares y de mil maravedíes también anuales, como exacción impuesta a todos los moradores del coto de San Esteban ${ }^{32}$. Las actividades del conde de Lemos y de Juan Pérez de Novoa, en representación suya como encomendero, se extenderían también al vecino monasterio de Santa Cristina

${ }^{29}$ BARros, C. Mentalidad justiciera, p. 193.

30 García, J. (1969). "Los señoríos monásticos gallegos en la Baja Edad Media (Notas y documentos sobre su volumen y evolución)”. Compostellanum, 14, pp. 545-622.

31 ACOrense. Pergaminos monacales, $\mathrm{n}^{\circ}$ 1862. Ed. DURO, E. (1977). El monasterio de San Esteban de Ribas de Sil. Orense: Instituto de estudios orensenos “padre Feijoo”, p. 293.

32 AHN, Sección clero, Carpeta 1562, nº 9. Ed. DuRo PEÑA, E. El monasterio, p. 327. 
de Ribas de Sil, reclamando veinte moyos de pan y vino ${ }^{33}$. Asimismo, el abad del monasterio de Santa María de Oseira no se libraría de la encomienda contra su voluntad de una granja, por la cual don Pedro obtenía cinco moyos de vino ${ }^{34}$. Las usurpaciones de heredades, y la exigencia del pago de tributos y servicios indebidos por parte del conde, también se desplegarían sobre señoríos ubicados fuera de la actual provincia de Orense, como en el caso de los monasterios de Sobrado, San Salvador de Lérez, Santa María de Meira e incluso en los cotos sujetos a jurisdicción del obispado de Lugo. Si bien el monarca, siempre daba la razón al forzoso encomendado, redactando sucesivas disposiciones con el fin de atajar las requisas derivadas de la encomienda, parece evidente que tales mandatos, en la mayoría de los casos, no dejaban de ser unas buenas intenciones casi nunca reflejadas en un auxilio real ${ }^{35}$.

Así pues, las dos clases antagónicas por excelencia del medio rural gallego, señores monásticos y labradores compartirían, bajo distintas modalidades y por diferenciados motivos, los desmanes del señorío laico.

\section{RESISTENCIAS CAMPESINAS CONTRA EL SEÑORÍO MONÁS- TICO}

En una época sujeta al preponderante peso que tenía el aprovechamiento de los recursos que la tierra otorgaba, sería imposible explicar cualquier acontecimiento histórico del periodo, sin tener presente las relaciones que de dicha explotación se derivaban. Así, como es obvio, la mentalidad del campesinado y las acciones consecuentes de la misma, en correspondencia con sus vínculos señoriales, constituyen un elemento básico para comprender el levantamiento irmandiño. Un proceso, que en su carácter de resistencia abierta, podría ser susceptible de quedar íntimamente ligado a un típico paradigma de la historiografía tradicionalconservadora, por el cual, los levantamientos acaecidos en el medio rural, sólo responden a estallidos esporádicos de violencia, originados en respuesta a una serie de ultrajes inaceptables, carentes por completo de programas y proyectos, y por

33 ACOrense. Pergaminos monacales, no 2952. Ed. FERNÁNDEZ, Elisa. (1974). "El monasterio de Santa Cristina de Ribas de Sil”. Boletín Auriense, 4, pp. 7-66.

${ }^{34}$ AHN, Sección clero, Carpeta 1550, nº 16. Ed. Romaní, M. et alii. Colección diplomática, Vol. III, p. 373.

${ }^{35}$ GARCíA, J. (1987). Galicia en los siglos XIV y XV, Vol. I. Pontevedra: Fundación Pedro Barrié de la Maza, p. 131. 
tanto, ajenos a la consecución en último término de una transformación social completa $^{36}$.

Sin embargo, la historiografía reciente ha otorgado más importancia a otras formas de resistencia latentes, que esconden un descontento campesino en progresión, y cuya evolución, en este caso, daría como resultado final el comienzo de una resistencia más abierta ${ }^{37}$, dentro de la cual ocuparían su lugar los movimientos antiseñoriales gallegos del XV.

Según la tipología tradicional elaborada por Porshnev, el levantamiento abierto constituía la forma de resistencia campesina primaria mientras que la resistencia parcial era considerada una modalidad secundaria. Variedad esta última, conceptualmente mejor definida con la denominación de latente, donde tendrían acogida los rechazos e infracciones individuales o colectivas hacia las obligaciones y prohibiciones señoriales, así como los pleitos elevados en defensa de los derechos campesinos. Por último, la huida en busca de unas mejores condiciones de existencia, también se acogería a este patrón de resistencias parciales ${ }^{38}$. Tampoco hay que olvidar, cierta oposición del labrador a la voluntad de su señor que por cotidiana no dejó de ser relevante. Se trata de las variantes de nocooperación, como la distracción de parte de la renta, los pequeños sabotajes y las demoras premeditadas $^{39}$. Y por supuesto, recordar la importancia que tuvo como forma de resistencia, ya desde la alta Edad Media, el conflicto entre señores y vasallos por el espacio agrícola y ganadero, necesario para estos últimos con el fin de atenuar su dependencia socioeconómica hacia los primeros ${ }^{40}$.

Buena parte de estas resistencias precedentes a la gran rebelión irmandiña, se recogen en el seno de la documentación monástica desde la segunda mitad del siglo XIII. Así, el quebrantamiento por parte del campesinado de la regulación foral, relativa al dominio útil de la tierra impuesta por los rectores monásticos, adquiere varias modalidades. Desde ocupar una parcela perteneciente al monasterio, sin

36 MousnIER, R. (1976). Furores campesinos: los campesinos en las revueltas del siglo XVII (Francia, Rusia, China). Madrid: Siglo XXI, pp. 38-55.

Fourquin, G. (1973). Los movimientos populares de la Edad Media. Madrid: Castellote Ed., pp. 40-105.

${ }^{37}$ RÖSENER, W. (1995). Los campesinos en la historia europea. Barcelona: Crítica, p. 106.

${ }^{38}$ Ibidem. (1990). Los campesinos en la Edad Media. Barcelona: Crítica, p. 252.

39 Freeman, P. (2000). "La resistencia campesina y la historiografía de la Europa medieval". Edad Media: Revista de Historia, 3, pp. 17-38.

${ }^{40}$ FERnÁnDEZ, F. J. (2004). La España de los siglos XIII al XV. Transformaciones del feudalismo tardío. San Sebastián: Nerea, p. 117. 
consentimiento alguno, y no pagar ningún tipo de renta ${ }^{41}$, pasando por seguir explotando la tierra, una vez que su aforamiento y voces hubiesen expirado ${ }^{42}$, llegando a eludir el pago de la renta ${ }^{43}$ y finalizando por el incumplimiento total o parcial de las obligaciones del foro ${ }^{44}$.

El rechazo del campesinado hacia las cargas que conllevaba el señorío, está presente en la contienda entablada entre el monasterio de Oseira y los habitantes del coto de Pedrafita debida al pago de la mañería y el conducho ${ }^{45}$. Esta actitud refractaria, también se hallaría en la negativa por parte de los vecinos de San Vicente de los Muros, relativa a satisfacer al obispo de Lugo la facendera ${ }^{46}$. En este último pleito, se hizo necesario el arbitraje de Alfonso $\mathrm{X}$, al igual que casi una década después, cuando en 1268, el rey hubo de dictar sentencia sobre el contencioso que mantenían, el monasterio de Santa María de Ferreira de Pallares con los habitantes de ciertas feligresías próximas, en razón al pago de hueste y huéspedes ${ }^{47}$.

No son tampoco infrecuentes, las tensiones derivadas del anhelo del campesinado por extender sus actividades agropecuarias, más allá de lo que el señorío permitía. Labradores que corrigen furtivamente lindes y demarcaciones, para ganar terreno de cultivo a costa de tierras sujetas al control monástico ${ }^{48}$, o aldeanos que se encuentran ante la oposición monástica y judicial a la hora de hacer valer sus pretensiones de explotar, mediante la tala y actividades ganaderas,

${ }^{41}$ ACOrense. Pergaminos monacales, no 1949. Ed. LuCAs, M. y LuCAS, P. (1996). El monasterio de San Clodio do Ribeiro en la Edad Media: Estudio y documentos. A Coruña: Seminario de estudos galegos, p. 446-447.

42 ACOrense. Pergaminos monacales, $n^{\circ}$ 1351. Ed. LuCAS, M. y LuCAS, P. (1996). El priorato benedictino de San Vicenzo de Pombeiro y su colección diplomática en la Edad Media. A Coruña: Seminario de estudos galegos, p. 113.

43 ACOrense. Pergaminos monacales, $\mathrm{n}^{\circ}$ 962. Ed. LuCAs, M. y LuCAS, P. El monasterio de, p. 338.

${ }^{44}$ ACOrense. Pergaminos monacales, $\mathrm{n}^{\circ}$ 1425. Ibidem, p. 400.

45 ACOrense. Pergaminos monacales, nº 522. Ed. Romaní, M et alii. Colección diplomática, Vol. I, pp. 464-465.

46 ACLugo. Libro 10, no 67. Ed. SÁnCHEZ, L. (1953). Documentos reales de la Edad Media referentes a Galicia. Catálogo de los conservados en la sección de clero del Archivo Histórico Nacional. Madrid: Servicio de publicaciones del ministerio de educación nacional, pp. 331-332.

${ }^{47}$ AHN, Sección clero, Carpeta 1091, n 2. Ed. SÁNCHEz, L. Documentos reales, pp. 341-342.

48 ACOrense. Pergaminos monacales, $n^{\circ}$ 2094. Ed. Romaní, M et alii. Colección diplomática, Vol. III, p. 32. 
ciertos montes ${ }^{49}$. Este último aspecto de rebeldía, es relevante ya que conlleva la creación de una asociación defensiva. Los labradores, agotados por las exacciones jurisdiccionales monásticas y al límite de los mínimos niveles de subsistencia, se agruparían para defender sus intereses ${ }^{50}$. Estos intereses se traducen en la intención, por parte de vecinos de comunidades de aldea, de alcanzar una delimitación beneficiosa relativa a la posesión de montes ${ }^{51}$, heredades ${ }^{52}$ y términos ${ }^{53}$, e incluso, de obtener todos los rendimientos derivados de las típicas construcciones, destinadas a la pesca fluvial o pesqueiras ${ }^{54}$. Explotaciones todas ellas, consideradas por los rectores monásticos, como apetecibles para extender su dominio señorial y fortalecer su patrimonio. Por otro lado, el interés de las comunidades aldeanas, no solo se conformaría con menoscabar en su beneficio el patrimonio territorial eclesiástico, sino que daría un gran paso, al orientarse incluso hacia la consecución de competencias jurisdiccionales. Esto fue, lo que al menos pretendieron los vecinos de Castrodor, a través de la demanda interpuesta contra el obispo de Mondoñedo, con la esperanza de que el rey confirmase la jurisdicción de los habitantes sobre su propia villa, alegando que eran de realengo y que la habían poblado según el fuero de Benavente ${ }^{55}$.

Este tipo de resistencias finalizarían en pleitos, documentos jurídicos que constituyen "la documentación más importante y esclarecedora" ${ }^{56}$ para el análisis de las resistencias y luchas campesinas a lo largo de la Edad Media. En la mayoría de los casos, estos pleitos se resolvían a favor del monasterio de turno, o bien tras un convenio arbitral entre las partes, o bien tras la retirada y renuncia de sus supuestos derechos por parte del demandante. Este tipo de resistencia por vía legal, siempre se ha visto por parte de la historiografía como mero ejercicio de futilidad.

49 AFP, 1/19. Ed. Fernández De Vianay Vieites, J. I. (1994). Colección diplomática del monasterio de Santa María de Ferreira de Pantón. Lugo: Diputación provincial de Lugo, pp. 39-40.

${ }^{50}$ PALlares, $\mathrm{M}^{\mathrm{a} C}$. (1979). El monasterio de Sobrado. Un ejemplo del protagonismo monástico en la Galicia medieval. La Coruña: Diputación provincial de La Coruña, p. 232.

${ }^{51}$ ACOrense. Pergaminos monacales, no 676. Ed. Romaní, M et alii. Colección diplomática, Vol. I, p. 618.

52 ACOrense. Pergaminos monacales, no 796. Ed. Romaní, M et alii. Colección diplomática, Vol. II, p. 776.

53 ACOrense. Pergaminos monacales, nºs 719 y 720. Ed. Romaní, M et alii. Colección diplomática, Vol. I, p. 684.

54 ACOrense. Pergaminos monacales, $n^{\circ}$ 3939. Ed. DuRo, E. El monasterio, pp. 378-381.

${ }^{55}$ AHN, Sección clero, Carpeta 1188, no 11. Ed. SÁNCHEZ, L. Documentos reales, pp. 387 y 407408.

56 PASTOR, R. (1990). Resistencias y luchas campesinas en la época del crecimiento y consolidación de la formación feudal. Castilla y León, siglos X-XIII. Madrid: Siglo XXI, p. 17. 
Algo en lo que no está en absoluto de acuerdo Isabel Alfonso Antón, para quien la relación entre señores y campesinos, se articula, en muchas ocasiones, a través de procesos de negociación y conflictos jurídicos, en los cuales estos últimos, mostrando capacidad jurídica en sus demandas y utilizando de forma estratégica los procedimientos judiciales, harían de los pleitos la plataforma donde desarrollar la conflictividad antiseñorial más cotidiana ${ }^{57}$. De hecho, se puede observar en la resolución de algunos pleitos, y más concretamente en los que la sentencia se estipula tras un acuerdo entre las partes, como el campesinado obtiene condiciones provechosas en metálico, tras, eso sí, la renuncia de sus derechos sobre ciertas propiedades en favor de los cenobios. De esta forma, Estevo Eanes y sus hermanos renuncian a todos los derechos que pudiesen tener en una viña recibiendo a cambio doscientos maravedíes a VIII $I^{\circ}$ soldos cada uun moravedi ${ }^{58}$. Por otro lado, nada menos que seiscientos sueldos pagaría el monasterio de Oseira por la renuncia de Mayor de Calvelo y de su hijo del casal de Samarugueiras ${ }^{59}$. A su vez, este mismo monasterio, entregaría quinientos sueldos a María Eanes a cambio de la renuncia de sus derechos sobre el casal de Sorveira ${ }^{60}$.

Otro tipo de resistencia, como se ha mencionado con anterioridad, la protagoniza la huida, la ruptura unilateral por parte del campesinado de su relación con el señor, en su anhelo por conseguir unas mejores condiciones de vida. Ya en 1182, se documenta como ciertos labradores, habitantes en los cotos del obispo de Lugo, abandonan sus tierras para irse a vivir a la villa, ante lo cual Fernando II, a petición del obispo, conmina a los burgueses e hidalgos, a no recibir a estos prófugos como vasallos. El abandono de las tierras de cultivo, y la marcha en búsqueda de los nuevos horizontes que proporcionaban los concejos y villas, también se registran un siglo más tarde, en 1281, cuando los habitantes de Villamayor se hacen vecinos de Monterrey, y en consecuencia, se niegan a prestar obediencia al abad de Santa María de Melón, y reconocer así su señorío. Ante este conflicto, el rey dictamina una resolución totalmente favorecedora a los intereses monásticos, restituyendo a los aldeanos contestatarios a su antiguo señorío y obligándoles a pagar luytosa e maninadigo e voz e calompnia ${ }^{61}$. Las mediaciones del rey, siempre propicias a las peticiones de abades y priores serían constantes.

57 Alfonso, I. (1997). “Campesinado y derecho: la vía legal de su lucha (Castilla y León, siglos X-XIII)”. Noticiario de Historia Agraria, 13, pp. 15-32.

${ }^{58}$ AHN, Sección clero, Carpeta 1536, nº 17. Ed. Romaní, M et alii. Colección diplomática, Vol. II, pp. 1118-1119.

59 AHN, Sección clero, Carpeta 1537, nº 1. Ed. Ibidem, pp. 1174-1175.

${ }^{60}$ AHN, Sección clero, Carpeta 1539, nº 9. Ed. Ibidem, p. 1247.

${ }^{61}$ AHN, Sección clero, Carpeta 1453, no 3. Ed. SÁNCHEZ, L. Documentos reales, p. 352. 
Así, en 1345, el monarca Alfonso XI dirige una carta a todos los concejos, justicias y demás autoridades de Galicia, motivada por la queja de los representantes del monasterio de Oseira

...et disen que ellos (el abad y sus capellanes) que an onbres siervos que lles fasen sus lavores et que los fasen menester en so monesteiro et estos tales que son suyos ellos et todo lo que ellos an et ovieren et non pueden ser de otro ninguno. Et que algunos de los dichos siervos que se fueron del dicho monasterio furtadamente a otras partes contra voluntad de los dichos abbad et convento, et que algunos de vos et de otros algunos de los dichos lugares que los anparan et los deffienden a ellos et a lo suyo... ${ }^{62}$

Aquí se aprecia que la resistencia no se circunscribe estrictamente a la huida, sino que se extiende a los lazos de solidaridad de otros algunos de los dichos lugares que los anparan et los deffienden a ellos et a lo suyo. Estos nexos de adhesión debieron de ser constantes y fuertes, puesto que, se hace necesaria treinta y cuatro años después, por parte de Juan II, una nueva disposición en beneficio del monasterio de Oseria, mediante la cual se, confirma la anterior carta de Alfonso XI, prohibiendo la acogida y protección de siervos fugitivos del referido cenobio ${ }^{63}$. Por otro lado, los gravámenes de carácter fiscal, constituirían un factor de importancia en la fuga de los pobladores de un determinado territorio. De este modo, en 1379, se hace preceptiva una cedula real de Enrique II, ordenando a Pedro Ruy Sarmiento, adelantado mayor de Galicia, que deje de exigir a los habitantes de los cotos y heredades del monasterio de Oseira, el pago de siete mil maravedíes por la qual rason disen que se yerman e despueblan los sus logares ${ }^{64}$. La huida como modo de resistencia señorial, también es necesario relacionarla con un proceso de intensificación de la inmigración rural en las villas gallegas, que desarrolla su máxima expresión entre los años 1300 y 1450 a raíz de la crisis que sufre el campo $^{65}$.

Aunque la resistencia quizá más característica en la documentación, sea aquella que se deja entrever subrepticiamente tras las diferentes condiciones, impuestas por los rectores monásticos, para hacer efectivos los contratos de aforamiento. Los campesinos habían de ser vasalos serventes et obedientes como condición básica

62 AHN, Sección clero, Carpeta 1546, nº 9. Ed. Romaní, M et alii. Colección diplomática, Vol. III, pp. 191-192.

${ }^{63}$ AHN, Sección clero, Carpeta 1550, nº 13.Ed. Ibidem, pp. 365-366.

${ }^{64}$ AHN, Sección clero, Carpeta 1550, no 11. Ed. Ibidem, pp. 362-363.

65 LÓPEZ, F. (1976). Introducción al fenómeno urbano medieval gallego, a través de tres ejemplos: Mondoñedo, Vivero y Ribadeo. Lugo: Universidad de Santiago, pp. 64-66. 
para recibir el dominio útil de la tierra. Si bien, bajo la evolución del derecho canónico, tomando como punto de partida las Decretales del papa Gregorio IX (1234), se percibe la incorporación de requisitos dentro del concepto del contrato, que atañen a la buena fe y la fidelidad a la palabra dada entre las partes concurrentes, no deja de ser por ello menos cierto, que en lo relativo a los contratos de aforamiento, tales formalidades, lejos de darse por supuestas, se especificaban como condiciones que asegurasen la integridad de los intereses monásticos, y sin las cuales, tal contrato quedaba sin validez. Así, términos como a boa fe et sen arte de engano, sen treiçon o sem malicia, serían comunes en los aforamientos. Es más, en las disposiciones finales de estos contratos, es común encontrar una cantidad variable en metálico, fijada por el monasterio, como pena a pagar por el incumplimiento de las condiciones estipuladas del mismo.

En consecuencia, no es extraño que en relación a la explotación del viñedo, cultivo de gran importancia a lo largo de la Edad Media, los cenobios necesitasen ciertas garantías, que diesen lugar a una buena labor que no menoscabase intencionadamente los rendimientos de estos cultivos.

Así, en 1436, el monasterio de San Pedro de Rocas, afora un monte con la condición que el forero plante viña en cinco años, sujeto a una renta del quinto de la producción, bajo la supervisión de dos monjes a vista de dous monjes ${ }^{66}$. De esta manera, la viña quedaría estrechamente ligada a un fuerte control monástico. Una férrea inspección que se extiende a las labores de vendimia, ya que el forero ha de pedir permiso al monasterio para poder iniciarla ${ }^{67}$, bajo la atenta mirada de un enviado suyo ${ }^{68}$. Una vez seleccionada la cantidad de vino que el forero había de satisfacer, para colmar las exigencias de la renta, en ocasiones, era el representante señorial y no este último, quien se encargaba de su transporte a la bodega del monasterio ${ }^{69}$, seguramente ante la tendencia del forero de "rebajar" el vino con agua $^{70}$, circunstancia que requería estrechar la supervisión por parte del cenobio ${ }^{71}$.

${ }^{66}$ ACOrense. Pergaminos monacales, $n^{\circ}$ 4020. Ed. DuRO, E. (1972). El monasterio de San Pedro de Rocas y su colección documental. Orense: Instituto de estudios orensanos “padre Feijoo”, p. 242.

$67 . .$. e non vindemedes sen mandado do dito mosteiro..., AFP., 2/126. Ed. FERNÁNDEZ DE VIANA Y VIEITES, J.I. Colección diplomática del., pp. 163-164.

68 ... et quando quiserdes vindymyar que chamedes ao ovençal...., ACOrense. Pergaminos monacales, $n^{\circ}$ 3357. Ed. DuRo, E. El monasterio, p. 336.

69 ... ao mordomo quando for saquar lo vino e algún se for con el...., ACOrense. Pergaminos monacales, $n^{\circ}$ 6172. Ed. DuRo, E. El monasterio de San Pedro, p. 271.

70 ...e nos pagaredes de foro por todo elo en vosa vida hun moyo de vino puro e sen augoa e sen maao sabor por día de San Martino de novembro en cada un anno...., AFP, 3/191. Ed. FERNÁNDEZ DE Viana Y VieiTes, J.I. Colección diplomática del., pp. 251-252. 
Paralela a esta estrecha fiscalización señorial de las actividades vitivinícolas del campesinado, que obliga incluso a la dedicación de manera exclusiva de algunos monjes al control de la producción de las familias campesinas ${ }^{72}$, se puede colegir una resistencia cotidiana fundamentada en el tenaz intento de acopio por parte del productor de parte de la renta destinada a su señor. Esta coyuntura, también se aprecia en la detracción del cereal ${ }^{73}$, e incluso en la explotación del estrato arbóreo. Así, en el momento que el forero quisiera talar madera de un soto aforado por el monasterio de Oseira, debería hacerlo delante de testigos que pudiesen dejar constancia de la buena fe del mismo, ante las autoridades monásticas ${ }^{74}$. Incluso, solapada bajo los estragos producidos por las heladas y los temporales, los rectores monásticos temerían la sustracción de cierta parte de la productividad, como se puede deducir en la práctica asumida por San Pedro de Rocas, de recurrir al arbitraje de terceras personas, siempre afines a los intereses monásticos, para llegar a una estimación exacta de los daños producidos por tales variaciones climatológicas ${ }^{75}$. Sería por tanto de vital importancia, para los rectores de los monasterios, contar con una amplia red clientelar, compuesta por milites y boni homines, que ayudasen a preservar sus bienes, de la amenaza germinada por las diversas contestaciones hacia el poder señorial ejercidas por el campesinado ${ }^{76}$.

... e que nos diades cada hun anno vos e as ditas persoas ao dito convento dous canados de vino por dia de San Martino de noviembro, que seja vino syn agua e syn malicia...., AFP, 1/84. Ed. Ibidem, pp. 219-220.

71 ...dos canados de vino sen agua o espeto da cuba por ollo de noso mordomo....., ACOrense. Pergaminos monacales, $n^{\circ}$ 4938. Ed. DuRo, E. El monasterio, p. 409.

72 ANDRADE, J. M. (1998). "Dentro y fuera del claustro: Aspectos de la vida cotidiana en torno a los monasterios medievales de Galicia”. En MEIJIDE, G. et alii. V e VI Semanas Galegas de Historia: Morte e sociedade no noroeste peninsular. Percorrido pola Galicia cotiá. Santiago de Compostela: Asociación Galega de Historiadores, p. 327.

73 LÓPEZ, J. A. (2006). “Aproximación al suelo habitable en la Ribeira Sacra durante los siglos XIV y XV”. Espacio, Tiempo y Forma. Serie III. Historia medieval, 19, pp. 293-303.

74 ...Et se tallardes do souto...chamaredes...homees...et quanto viren que tallardes..., AHN, Sección clero, Carpeta 1543, nº 2. Ed. RomAní, M et alii. Colección diplomática, Vol. III, pp. 70-71.

75 ... Et he posto entre nos e vos que se veer grando ou geada que seia estimado por dous lavradores da dita villa et por hun frade do dito mosteiro..., ACOrense. Pergaminos monacales, $\mathrm{n}^{\circ}$ 2514. Ed. DuRo, E. El monasterio de San Pedro, p. 192.

... E posto entre vos e o mosteiro se veer grando ou geada ou tolemento que sega estimado por II homees boos lavradores da dita frixigía e por huun frade do dito moesteiro..... ACOrense. Pergaminos monacales, $\mathrm{n}^{\circ}$ 2672. Ed. Ibidem, pp. 202-203.

${ }^{76}$ ALFONSO, I. (1990). "Poder local y diferenciación interna en las comunidades rurales gallegas". En PASTOR, R. (comp.). Relaciones de poder de producción y parentesco en la Edad Media y Moderna. Madrid: CSIC, pp. 203-223. 
Como se puede apreciar en consonancia con lo hasta aquí relatado, si bien son destacables las connotaciones especiales que caracterizan al levantamiento irmandiño, como encarnación de la afirmación violenta por antonomasia proyectada desde el antagonismo social rural gallego, no lo es menos, la relevancia que en periodos precedentes e incluso posteriores, tuvo otro tipo de resistencia campesina desarrollada de manera larvaria, bajo aquellos aspectos menos palpables de la vida cotidiana.

Unas formas de resistencia latentes, que desembocarían en el siglo XV hacia un estallido de violencia, en el que, como es obvio, participaría a modo de causa, común con el resto del reino, una crisis del sistema feudal derivada del descenso demográfico, la crisis agrícola, la devaluación de la moneda y en consecuencia, el alza de precios ${ }^{77}$. Con el objetivo de mantener los ingresos nobiliarios ante tan perjudicial coyuntura, se abre un proceso de "reseñorialización" del campo, esto es, la adecuación a las nuevas circunstancias de crisis, a través de la reorganización del poder feudal que no duda en usar sus potestades jurisdiccionales (y las que no tiene), con el fin de coaccionar al campesinado para arrebatarle su excedente agrícola $^{78}$. En lo relativo al señorío monástico, se aprecia como pauta generalizada, tras la segunda mitad del siglo XIV, la exigencia de foros de más corta duración, y de rentas más gravosas, con el fin de corregir la disminución del rendimiento del patrimonio señorial y paliar así, los efectos de la crisis, consecuencia del retroceso demográfico ${ }^{79}$. La actuación de la nobleza frente a la crisis, no haría más que eliminar de la conciencia campesina, si alguna vez estuvo arraigado, el concepto de estamento encargado del orden y la protección de los más débiles en el seno de la sociedad trifuncional. Por otro lado, la respuesta de la iglesia ante los infortunios de la época, se limitaría solamente a culpar a las masas de los mismos por sus pecados, con el fin de mantener la dominación de las almas de una feligresía vacilante ante el déficit espiritual de los clérigos. ${ }^{80}$ En el medio rural gallego, donde el señor y el pastor de ánimas, en la mayoría de las ocasiones, respondían a una misma realidad, la desarticulación del modelo ideológico del sistema feudal transmutaría, con más virulencia si cabe, el malestar popular en una serie de

77 Engels, O. (1993). "La crisis en Castilla durante el siglo XIV”. En SEIBT, F. y EBERHARD, W. (eds.). Europa 1400. La crisis de la baja Edad Media. Barcelona: Crítica, pp. 213-224.

${ }^{78}$ Guinot, E. (2003). La baja Edad Media en los siglos XIV-XV. Economía y sociedad. Madrid: Síntesis, p. 206.

79 Álvarez, E. (1983). “Las exigencias señoriales en la Galicia meridional a través de la duración y la renta de los contratos de foro (1340-1450)”. Cuadernos de estudios gallegos, 34, pp. 117-152.

${ }^{80}$ BoIs, G. (2001). La gran depresión medieval: siglos XIV-XV. El precedente de una crisis sistemática. Valencia: Universitat de Valencia, pp. 128-141. 
convulsiones sociales que precederían al levantamiento irmandiño de 1467. Así, de 1382 a 1457 los vecinos de Orense (en tres ocasiones: 1382-1385, 1419 y 1455), de Lugo (en otras tres: 1386, 1403 y 1457) y de Santiago (en dos: 1418-1422 y 14581459), dirigirían sus iras hacia sus respectivos obispos mediante revueltas armadas $^{81}$. Sin embargo, el antecedente más claro del movimiento irmandiño hay que buscarlo en 1431, en la llamada "primera guerra irmandiña" o hermandad fusquenlla y en 1451, año en que se produjo un levantamiento generalizado en las rías de Arousa y Pontevedra. En ambas ocasiones, el malestar de los sublevados se orientó hacia casas fuertes ${ }^{82}$ y fortalezas ${ }^{83}$, las cuales derribaron. Un claro indicio de lo que sucedería poco tiempo después.

\section{EL CAMPESINADO, UNA CLASE SOCIAL DIVERSIFICADA}

El cuestionamiento del campesinado del sistema teorético de estructuración social, persistente con mayor o menor fortuna desde el siglo XI, liberó en su mente cualquier tipo de contención que reprimiese su deseo de hacer justicia, frente los agravios cometidos por aquellos que tendrían que garantizar la paz y el orden. De manera que, en Galicia, los estratos sociales más populares, amparándose en el movimiento irmandiño, equipararían su cometido con la línea de actuación del estado moderno, al intentar recobrar del señorío feudal, parte de sus jurisdicciones cedidas desde la alta Edad Media, otorgando gran relevancia a la administración de justicia, y dirimir así, la crisis de un sistema hasta entonces hegemónico ${ }^{84}$.

Es notorio que estuvo muy arraigada en la historiografía marxista, la visión de un mundo rural, que aunque integrante de la sociedad feudal casi al completo, es considerado poseedor de un nivel intelectual demasiado primitivo y rudimentario, como para protagonizar un cambio del sistema precapitalista. En consecuencia, esta doctrina extendió una percepción plena de perjuicios sobre el campesinado como actor socio-histórico, relegándolo a la condición de mero observador pasivo, o en su defecto, a la de participante indirecto y circunstancial, en el momento de secundar una ideología revolucionaria, sólo exclusiva de las clases urbanas. Una visión parcialmente disconforme surge desde el materialismo histórico inglés con la figura de Rodney Hilton. Bien es cierto, que este autor defiende que los sacerdotes, actuando como vehículos transmisores, lograron que el campesinado

${ }^{81}$ BARros, C. Mentalidad justiciera, pp. 24 y 32-33.

82 Pérez De Guzmán, F. (1953). “Crónica de Juan II”. Crónica de los reyes de Castilla, Vol. II. Madrid: Boletín de Autores Españoles, p. 453.

83 Rodríguez, Á. Las fortalezas de, p. 353.

84 BARros, C. (2002). "La mentalidad justiciera en las revueltas sociales (edades media y moderna)". Mentalities/Mentalités, 17, pp. 32-44. 
asumiese como propia, la doctrina de la clase dominante relativa al puesto que a cada uno le correspondía en el seno de la sociedad trifuncional ${ }^{85}$. En consecuencia, el campesinado medieval, si tenía una conciencia de clase, esta sería negativa, es decir, aquella adoptada de sus enemigos y no la suya propia, que le llevaría a la defensa de la costumbre ancestral ante cualquier tipo de innovación ${ }^{86}$. Sin embargo, Hilton desposee al mundo urbano de cualquier relevancia en el movimiento inglés de 1381, otorgando a éste una fuerte impronta rural. Es el campesinado, y no el habitante de la ciudad, el que conforma la clase antifeudal por antonomasia. Naturalmente, con el fin de evitar un total alejamiento de la enunciación marxista, del interior de una masa campesina general, sin conciencia de clase propia, inmovilista y atada a una visión del mundo proyectada desde la jerarquía social, han de brotar cuadros dirigentes dispares y detentadores de una naturaleza protocapitalista, motivadora en última instancia de la sublevación contra un régimen socioeconómico en crisis y constrictivo de su prosperidad personal ${ }^{87}$.

Sería erróneo pensar en una masa rural encuadrada en una única clase social, homogénea y depauperada, como agente activo de los levantamientos señoriales. Un ejemplo claro de ello se encuentra en la guerra abierta de los pageses de remença catalanes. Un movimiento emancipador, en el que las primeras manifestaciones del descontento campesino se revelan entre los años 1380 y 1390, y que no concluiría hasta la promulgación de la Sentencia Arbitral de Guadalupe de 1486. A lo largo de este conflicto armado, los síndicos remensas ofrecerían hasta cien mil florines al rey Alfonso el Magnánimo, para garantizarse la intervención del monarca en favor de sus demandas. Intervención que se traduciría en la Sentencia Interlocutoria mediante la cual, se suspendía provisionalmente la prestación de los malos usos ${ }^{88}$. La abolición definitiva de los mismos, no se produciría hasta la entrada en vigor de la Sentencia Arbitral de Guadalupe, eso sí, también previo pago de cierta cantidad en metálico, en concreto diez sueldos por cada mal uso, montante que se incrementaría a razón de un interés del cinco por ciento anual mientras no se abonase la cantidad en su totalidad ${ }^{89}$. Así pues, la acumulación de riqueza por parte del campesinado, más allá de la violencia de sus actos, resultaría el factor decisivo, que confirmase la abolición definitiva de estas inicuas cargas jurisdiccionales. Una nueva condición, a la que sólo accederían el sector del campesinado más acomodado, enriquecido a costa del empobrecimiento

\footnotetext{
${ }^{85}$ Hilton, R. (1988). Conflicto de clases y crisis del feudalismo. Barcelona: Crítica, p. 18.

${ }^{86}$ Ibidem. Siervos liberados, pp. 71-172.

${ }^{87}$ Ibidem. Conflicto de clases, pp. 49, 76 y 89.

${ }^{88}$ ViCENS I ViVES, J. (1988). Els trastàmares (segle XV). Barcelona: Vicens-Vives, pp. 24-31.

${ }^{89}$ BeLenguer, E. (1999). Fernando el Católico. Barcelona: Península, p. 165.
} 
de una mayor parte del mismo, cuya única vía de acceso a la tierra era mediante los contratos de masoveria ${ }^{90}$ o arrendamiento de un mas.

En el seno del campesinado gallego, también se puede observar la presencia de una diferenciación económica, derivada de la venta en el mercado de excedentes agrícolas, así como de la posesión de ganado vacuno. Ya a lo largo del siglo XIV, los rectores monásticos exigían a algunos de sus foreros que aportasen su propio ganado, para garantizar la buena explotación del bien aforado ${ }^{91}$. El mínimo exigible sería el de dos bueyes, número que se repite con asiduidad en los aforamientos de ciertos monasterios $^{92}$. Dada la relación existente entre la posesión de bueyes y la posibilidad de explotar una mayor extensión de terreno cultivable, y que la detentación de menos de dos bueyes es claro síntoma de un campesino empobrecido $^{93}$, parece evidente una clara diferenciación económica entre el campesinado, ya que no todos sus miembros podían concurrir con la ganadería exigida por los rectores monásticos ${ }^{94}$. Uno de los condicionantes que recrudecerían esta diferenciación, se encuentra en la fragmentación que sufre la propiedad de la tierra a partir del siglo XIII, a causa del crecimiento demográfico, y a la consiguiente transmisión hereditaria ${ }^{95}$. De esta manera, y ya en el siglo XV, se documentan en el actual municipio de Pantón propiedades alodiales de una superficie no mayor de dos a dos y media tegas de sembradura ${ }^{96}$, es decir, de

${ }^{90}$ Bolòs, J. (1995). El mas, el pagès i el senyor. Barcelona: Curial, pp. 137-142.

91 ...et que tragades o casar pobrado de hun juyo de boys e de hua vaca e de seys rogellos que seian voso o cabo..., AFP., 1/26. Ed. Fernández De ViAnA Y VIEITES, J. I. Colección diplomática del., p. 46.

...e tragerdes senpre o cassar povrado de dous boys pera lavrar e de dúas vacuas e de doze rexellos..., AFP., 1/30. Ed. Ibidem, p. 51.

${ }^{92}$ Mariño, D. (1983). Señorío de Sta. María de Meira (s. XII-XVI). La Coruña: Ediciones Nos, p. 313.

93 Clemente, J. (2004). La economía campesina en la corona de Castilla (1000-1300). Barcelona: Crítica, p. 81.

94 Ríos, MaL. (1997). “Transformación agraria. Los terrenos de monte y la economía campesina (s. XII-XIV)”. En TORRES, MP. et alii (coord.). Espacios rurais e sociedades campesiñas. Santiago de Compostela: Universidad de Santiago de Compostela, pp. 145-172.

95 Portela, E. (1979). "Propiedad y formas de explotación de la tierra en la Galicia medieval”. En ANES, G. et alii (coord.). La economía agraria en la historia de España. Propiedad, explotación, comercialización, rentas. Madrid: Alfaguara, pp. 123-131.

96 ...Et poreste ben e graçia que eu recibo do dito mosteiro enpraço e dou ó dito mosteiro a mia erdade que jas a Villa da Careyra.... que seerá dúas teegas sementadura...., AFP., 2/126. Ed. FERNÁNDEZ De Viana Y Vieites, J. I. Colección diplomática del., p. 164. 
aproximadamente 817 a $1226 \mathrm{~m}^{2}$. Unas dimensiones que se perpetuarían a lo largo del Antiguo Régimen, al ser similares a la extensión de la parcela media en otras localidades lucenses, estudiadas por Villares Paz para el siglo XVIII ${ }^{97}$. Explotaciones que por si mismas imposibilitaban la reproducción de una unidad familiar $^{98}$, y que estaban muy lejos de las veinte hectáreas susceptibles de ser trabajadas por un campesinado enriquecido ${ }^{99}$. En consecuencia, el campesino para garantizarse el sustento no tendría más remedio que poseer varias de estas pequeñas explotaciones ${ }^{100}$, o incluso cederlas al señorío monástico a cambio del aforamiento de otras tierras mucho más productivas ${ }^{101}$. No sólo el alodio, sino también el dominio útil, se vería afectado por este proceso de pulverización parcelaria. Circunstancia extraña, ya que estas explotaciones monásticas eran hereditariamente indivisibles. Varios factores pueden explicar este fenómeno. Por un lado, la inviabilidad de la unidad familiar para obtener rendimientos de explotaciones más amplias, o en caso contrario, la negativa del monasterio a ceder en foro mayores extensiones, ante el temor de que el campesinado lograse excedentes suficientes para mitigar su relación de dependencia ${ }^{102}$. Por otro, que efectivamente se hiciesen particiones en contra de las disposiciones del contrato ${ }^{103}$.

Un camino alternativo del campesinado empobrecido, y con dificultad para asegurar su subsistencia sujeta a la ínfima productividad de estas porciones de tierra, sería el de poner sus brazos al servicio monástico por un sueldo.

... Et posto este ben e merçede que vos recibo et do dito voso mosteiro vos implazo de enprazo a miña leira do Chao que he dicimo a Deus, que son dúas tegas semente...., AFP., 3/195. Ibidem, p. 259.

97 En concreto en tierras del Salnés, Burón y Friol. VILLARES, R. (1982). La propiedad de la tierra en Galicia 1500-1936. Madrid: Siglo XXI, p. 25.

${ }^{98}$ VAsSALlo, R. (2004). "Diferenciación social campesina en concejos de abadengo (siglos XIIIXVI). Mundo agrario. Revista de estudios rurales, 9, pp. 1-17.

${ }^{99}$ Clemente, J. La economía campesina, p. 73.

100 ...vendemos a vos don Afonso Gonçales, prior do moesterio de San Viçenço de Pombeiro... huna leyra de herdade a que chaman de Ribeyra con seu terreo, que son duas teegas e medea de pan sementadura. Outrosy vos vendemos mays con esto que sobredito he outra leyra a que chaman do Salgueyro e con outra leyra de Coto de Rey, que seeran anbas çinquo teegas de semente...., ACOrense. Pergaminos monacales, $n^{\circ}$ 3930. Ed. LuCAS, M. y LuCAs, P. El priorato benedictino de, p. 197.

${ }^{101}$ Ver nota 86. Además AFP., 2/113 y AFP., 2/124. Ed. Fernández De VianA Y VieItes, J. I. Colección diplomática del., pp. 145 y 161 respectivamente.

102 SÁnCHEZ, Ma C. (1997). El Bajo Miño en el siglo XV. El espacio y los hombres. A Coruña: Fundación Pedro Barrie de la Maza, p. 122.

103 Bohuier, A. (2001). Ensaio xeográfico de análise e interpretación dun vello complexo agrario, Vol. II. s.l: Xunta de Galicia, p. 1319. 
Proletización de parte del campesinado, que ya se puede apreciar a mediados del siglo XIII ${ }^{104}$ y que tras una gran progresión, tres siglos después se convertiría en un elemento de gran trascendencia en el seno del setenta por ciento de la población gallega $^{105}$.

No atenuaría la crítica situación del medio rural, pese al gran protagonismo que toma el esfuerzo roturador del campesinado, subyugado a los intereses de los cenobios, en su lucha por hacer productivo el baldío, el hecho de que en el siglo $\mathrm{XV}$, la recuperación demográfica en el campo gallego, alcanzase unas cifras poblacionales muy superiores en proporción a las tierras puestas en explotación, las cuales no llegarían a un doce por ciento del total ${ }^{106}$.

Otra vía que fomentó la diferenciación socioeconómica en el seno del agro gallego, estuvo estrechamente vinculada a una política monástica orientada a fortalecer alianzas estratégicas con destacados miembros de la comunidad rural, siempre dispuestos a favorecer las relaciones de poder señorial sobre el resto de campesinos productores, a cambio de condiciones más favorables en sus contratos de aforamiento $^{107}$. En un principio, los receptores de estas concesiones contractuales fueron los miembros de la nobleza laica, intermediarios más que adecuados, para garantizar la puesta en explotación de ciertas propiedades monásticas, y para actuar como agentes defensores del patrimonio de las instituciones eclesiásticas. Pero a partir de finales del siglo XIII, se aprecia con más frecuencia en la documentación, la presencia de campesinos enriquecidos cumpliendo con dicha labor ${ }^{108}$.

Estos nexos sociales selectivos, promoverían la diferenciación interclasista en el seno del campesinado, allanando la quiebra de su cohesión interna. Esta diferenciación queda reflejada, en una jerarquía socioeconómica derivada de los diferentes grados de acceso al dominio útil monástico. Así, en la cúspide de este

${ }^{104}$ AHN, Sección clero, Carpeta 1521, nº 10. Ed. Romaní, M et alii. Colección diplomática, Vol. I, pp. 477-478.

105 GonZÁlez, E. (1980). La Galicia de los Austrias, Vol. I. A Coruña: Fundación Pedro Barrié de la Maza, p. 129.

${ }^{106}$ RuIZ, J. (1948). La población de Galicia (1500-1945). Madrid: CSIC, p. 269.

107 Alfonso, I. (1990). "La comunidad campesina”. En PASTOR, R. et alii. Poder monástico y grupos domésticos en la Galicia foral (siglos XIII-XV). La casa. La comunidad. Madrid: CSIC, pp. 303-372.

108 Ríos, M ${ }^{a}$ L. (1992). "Estrategias señoriales en Galicia: las instituciones eclesiásticas y sus relaciones contractuales con la nobleza laica (1150-1350)". En PASTOR, R. et alii. Poder y sociedad en la Galicia medieval. Santiago de Compostela: Tórculo Edicións, pp. 175-189. 
organigrama, se situarían los foreros de uno o varios casares, precediendo a aquellos que se han de conformar con una sola tierra, y relegando a un último lugar a los que sólo reciben el foro de una pequeña parcela ${ }^{109}$. A fin de cuentas, fue la diversidad el rasgo más característico del campo medieval ${ }^{110}$.

Lógicamente, las víctimas propiciatorias de los desmanes señoriales, fueron aquellos que más tenían que aportar. Los delitos que contra ellos se cometieron, responden a dos grandes tipologías: el robo de ganado bovino y los rescates rurales. Algunos de estos últimos tan cuantiosos, que no hacen sino poner énfasis en la existencia de una clase labradora enriquecida ${ }^{111}$.

Al constituir el sector social más agraviado, es coherente su interés en participar en el levantamiento ${ }^{112}$. Sin embargo la diferenciación social del campo gallego parece diluirse, en aras de una reacción antiseñorial capaz de aglutinar a ochenta mil sublevados en todo el reino de Galicia ${ }^{113}$ o de doce a quince mil sólo en el condado de Lemos y alfoz de Chantada ${ }^{114}$. Es difícil explicar este contingente humano, soslayando una participación masiva y sin distingos por parte del campesinado. Un condicionante favorecedor de esta implicación campesina homogénea, hay que buscarlo en la evolución de las exigencias señoriales a lo largo del siglo XV. Si bien es cierto que durante este periodo, se hace patente una mitigación de las rentas derivadas de los contratos de foro, así como un aumento de la duración de los mismos ${ }^{115}$, no lo es menos una tendencia por parte de los rectores monásticos, dirigida al incremento de exacciones de tipo jurisdiccional como la luctuosa $^{116}$ o el yantar ${ }^{117}$. Inclinación, que no hace sino fortalecer un sentimiento colectivo de agravio en el marco del campo gallego.

109 DEAÑo, C.A. (2004). Rivadavia y su comarca en la Baja Edad Media. A Coruña: Seminario de Estudios Gallegos, pp. 141-142.

${ }^{110}$ Genicot, L. (1993). Comunidades rurales en el Occidente medieval. Barcelona: Crítica, p. 154.

111 Tras el arresto e incluso la tortura los labradores tendrían que comprar su libertad por una cantidad variable que iría de los diez mil maravedíes o las ochenta doblas de oro como cantidades máximas RoDRíGUEZ, Á. Las fortalezas de, pp. 450-451 y 372, respectivamente, a las diez doblas de oro como montante mínimo, Ibidem, p. 447.

112 BARros, C. Mentalidad justiciera, pp. 169-185.

113 RodRíGUEZ, Á. Las fortalezas de, p. 345.

114 Ibidem, p. 503.

115 ÁLVAREZ, E. “Las exigencias señoriales en, p. 131.

116 PASTOR, R. (1990). “Poder monástico y grupos domésticos foreros”. En PASTOR, R. et alii. Poder monástico y, pp. 49-234. 
No obstante, en los testimonios favorables al arzobispo saliente Fonseca frente a los del entrante Tabera, en el pleito relativo a la reparación de las fortalezas circunscritas a la mitra compostelana, se puede colegir una composición social nada variada del campesinado como primer actor del levantamiento. Los relatos nos muestran una masa de labradores unidos en la miseria

...e dize este testigo que la gente de labradores son probes que no tiene propiedades y biben en casas agenas... ${ }^{118}$

...son muy pobres de tal manera que muchos dellos y la gente comun no tienen con que se mantener ni los labradores alcanzan bois con que labrar y no tienen propiedades sino muy pocas... ${ }^{119}$

Sin embargo, no hay que eludir el interés del arzobispo Fonseca de evitar cualquier acusación de negligencia, presentando un campesinado carente de recursos, sobre el que le sería imposible hacer recaer la responsabilidad de la reconstrucción de las fortalezas.

Los testimonios presentados por la parte de Tabera, reflejan una composición social de los labradores más variada.

Lopo Afonso, zapatero y vecino de la ciudad de Lugo, atestiguaría que el conde de Lemos, considerando culpables a sus vasallos labradores del derrocamiento de las fortalezas derribadas en Sarria y Monforte, les obligaría a reconstruirlas, a costa de su sudor o de su pecunio dependiendo de su situación económica

...porquel testigo dize que bido que los labradores pobres iban a serbir e carretar la piedra e otras serbintias a las dichas fortalezas y quel mismo conde yba en una mula con una bara en la mano dandoles en la cabeza deziendoles: carretad, villanos, que bien recios andabades en derribar mis casas... y labradores ricos les tomaba e azia pagar dineros y marabedis para ayuda y reparo de las dichas fortalezas... ${ }^{120}$

Por su parte, Juan Rodríguez, vecino de una aldea cercana a Monforte de Lemos, profundiza en la diferenciación económica de la gente de la tierra de Lemos responsable de los derrocamientos, relacionándola con la posesión de bueyes

117 ÁLVAREZ, Eleutino. (1983). "El yantar y el hospedaje foral en el sur de Galicia. (1340-1450)”. Boletín Auriense, 13, pp. 137-144.

${ }^{118}$ RodRíGuEZ, Á. Las fortalezas de, p. 346.

119 Ibidem, p. 364.

120 Ibidem, p. 138. 
...que los que benian con bois e carro no serbian con su persona sino los que traian carro aquellos serbian con las personas de lo que hera necesario... ${ }^{121}$

Que el conde de Lemos no hacia distingos, mientras correspondiesen con su trabajo o dinero, entre labradores ricos y empobrecidos, equiparándoles en la misma categoría de partícipes de la insurrección a la hora de exigir la reedificación de sus fortalezas, queda claro en el testimonio de Rodrigo Donbrero, alcalde y merino de la torre del Padron. Aquí se relata como un labrador exigió al conde un nuevo buey, al habérsele muerto otro con anterioridad, durante las tareas de reconstrucción de la fortaleza de Ponferrada. La reacción del conde fue estentórea

...hi de puta villano que hos fazian a bos mis fortalezas queseaban fechas que si bos y los otros mis basallos no me las derrocades no hos las mandara hazer... ${ }^{122}$

No obstante, acto seguido, enviaría un criado a la morada del labrador para asegurar su presencia en las obras con otro buey, y a la vez determinar su condición económica, ya que

...si hera tan pobre como dezia e si lo hera que le diese e comprase otro buey e si hera rico que lo comprase el... ${ }^{123}$

También Diego de Andrade, consideraría máximos responsables del derribo de las fortalezas de la casa de Andrade a sus vasallos y personas de la tierra, y siguiendo la línea de actuación de su homólogo en la Tierra de Lemos, les exigiría su reconstrucción ${ }^{124}$. Una labor que iría pareja, tanto a los servicios de prestación de trabajo, como a la obligatoriedad, dirigida a los labradores, de establecer un repartimiento de dinero con el que pagar a los oficiales y maestros de obras traídos de Vizcaya. Las cuantías no se precisan en el caso de la reedificación de las fortalezas de Andrade, pero si son explícitas en el caso de las tierras del conde de Lemos. Cantidades que variaban de dos a diez reales, dependiendo del patrimonio de las distintas casas objeto de exacción ${ }^{125}$, lo cual no hace sino reafirmar la diversidad económica del campesinado protagonista de la insurrección.

\footnotetext{
${ }^{121}$ Ibidem, p. 170.

122 Ibidem, p. 244.

123 Ibidem

${ }^{124}$ Ibidem, pp. 103 y 143.

125 Ibidem, p. 156.
} 


\section{EL CAMPESINADO COMO PRINCIPAL ACTOR ANTIFEUDAL DEL MOVIMIENTO IRMANDIÑO}

Como se ha señalado con anterioridad, uno de los paradigmas más manidos en el discurso de cierta parte de la historiografía marxista conservadora, es el relativo a desposeer al campesinado de capacidad de dirección en los movimientos antiseñoriales, relegándolo al mero papel de comparsa de las voluntades de otros agentes, por lo general procedentes del entorno urbano y burgués. Un campesinado, considerado como una masa necesaria, por su carácter cuantitativo en cualquier manifestación violenta, pero carente de cualquier voluntad política propia.

Una aproximación relativa a la extracción social de los dirigentes de la hermandad, según de lo que se desprende de la sucesión de testimonios de los que costa el Pleito, concluye la siguiente relación: Alfonso de Camba, zapatero, Juan Cabaneiro y Pedro García de Cangas, pescadores ambos y todos alcaldes de hermandad de la villa de Pontevedra ${ }^{126}$, Fernando Sobrado y Gonzalo de Vilasuso, zapateros y diputados de hermandad en la ciudad de Betanzos ${ }^{127}$, Juan de Pans, sastre, Ares Alfonso, platero y Fernán Rodero, boticario, prinçipales en la dicha hermandad de la ciudad de Santiago de Compostela ${ }^{128}$, García Cordo, labrador y alcalde de la feligresía de Lestedo ${ }^{129}$, Bartola de Freira, labrador y capitán de la hermandad de Ribadulla, junto con Álvaro de Anguería, escudero y alcalde de hermandad de la villa de Padrón ${ }^{130}$, Álvaro López de Ferraria, executor de la dicha hermandad (alcalde de la hermandad de Lugo) y escudero, Pedro Méndez de Fornins, canónigo de la Iglesia Mayor de Lugo y diputado de la hermandad de dicha ciudad, los bachilleres Martín Troco diputado por Santiago y Patiño diputado por la Coruña ${ }^{131}$, Juan Branco y Ruy de Sarandon, labradores y alcaldes de la hermandad de Puente de Ulla ${ }^{132}$, Juan Domínguez, carnicero y alcalde de la hermandad de Pontevedra ${ }^{133}$, Vasco de Vilachán, zapatero y alcalde por la Proba Daban ${ }^{134}$, Juan Branco, capitán de hermandad en la ciudad de Betanzos y

\footnotetext{
126 Ibidem, p. 408.

127 Ibidem, p. 429.

128 Ibidem, p. 313.

129 Ibidem, p. 317.

130 Ibidem, p. 550.

131 Ibidem, p. 485.

132 Ibidem, pp. 348-349.

133 Ibidem, p. 383.

134 Ibidem, p. 482.
} 
escribano $^{135}$. En consecuencia, las referencias muestran a cuatro zapateros, un sastre, un carnicero, un platero, un boticario, dos bachilleres, un canónigo, un escribano, dos escuderos, dos pescadores y cuatro labradores. No obstante, hay que tomar estos testimonios con cierta precaución. En primer lugar, porque la memoria de los testigos parece seleccionar con una mejor disposición, en detrimento de sus oficios o su estatus social, solamente los nombres de los miembros de las hermandades, lo que limita una visión más amplia de la composición social de sus órganos rectores. En segundo lugar, por que el recuerdo sólo conserva el dominio de lo más próximo o familiar. Así, la preponderancia de miembros del entorno urbano frente a habitantes del medio rural, se podría colegir atendiendo a una determinada particularidad, la que indica que de los diez testimonios en los que se menciona el origen social de los dirigentes irmandiños, ocho proceden de habitantes de ciudades y únicamente dos del entorno rural. Pese a ello, de estas declaraciones se puede deducir, que el mundo campesino quedaba representado en la dirección de las hermandades, sin circunscribirse exclusivamente dentro de un segundo plano en las líneas de actuación de las mismas. De hecho, en ciertas áreas de Galicia, el protagonismo rural en el curso del levantamiento, alcanzó una significación absoluta. Es el caso de la Tierra de Lemos, donde las hermandades se organizan haciendo junta e acuerdo e conçejo, no en el interior de la villa como sucedería en otras localidades gallegas, sino en el monte Fabeiro a un cuarto de legua de Monforte ${ }^{136}$. Una vez formada la hermandad se lanzarían sus miembros contra esta villa, logrando reunir ya en su interior, concretamente alrededor del monasterio de San Antonio, de cinco mil a seis mil hombres, que acto seguido se encargarían de tomar la fortaleza ${ }^{137}$. Fortaleza, que en su derribamiento no participarían los vecinos de Monforte, por lo cual, tras la derrota irmandiña, estarían exentos de servir en su reconstrucción ${ }^{138}$. Este episodio, acaecido en Tierra de Lemos, parece poner en entredicho, la tan necesaria como imperante función directiva que se ha venido concediendo al marco urbano en los movimientos sociales. Semejante línea de pensamiento, confiere a la ciudad la condición de máximo referente del progreso burgués, en cerrada dialéctica con la estructura socioeconómica feudal, identificada con el mundo agrario que la envuelve. La metáfora de lo urbano como islote de libertad, extraño al modo de producción feudal. Sin embargo, el medio urbano estaría estrechamente relacionado con el campo y con las actividades realizadas en él. Es por este motivo, que en las

\footnotetext{
135 Ibidem, p. 420.

${ }^{136}$ Ibidem, p. 165.

137 Ibidem, p. 162.

138 Ibidem, p. 158.
} 
ordenanzas y mandamientos del concejo de Orense, se tengan que incluir disposiciones para evitar que el ganado equino provoque destrozos en las viñas dentro de la ciudad ${ }^{139}$. Un hecho, que pone de manifiesto la presencia de una población agrícola en el seno de esta localidad, se encuentra en la querella presentada contra Afonso Esteves al que se le acusa de

...que eno ano de XLVI, eno mes de feuereiro et de março, que tomou erobou aos vesiños da dita çidade, que labrauan viñas arredor do castello, fasta mill meollos e levoos ao castello... ${ }^{140}$

La presencia de una población agrícola en el interior de villas y ciudades, armonizaría con la implicación de los vecinos de la misma en actividades de explotación de huertas y viñas, dejando solamente la carne, el cereal y la sal, como únicos productos de obligada adquisición fuera del entorno más próximo ${ }^{141}$. En consecuencia, como indican los contratos de foro, los artesanos compaginarían sus labores profesionales con el cultivo de las tierras ${ }^{142}$. Esta miscelánea de elementos urbanos y rurales, constituiría el rasgo característico de las ciudades y villas gallegas. De esta forma, no es de extrañar que la empatía que despiertan los labradores en el mundo menestral, les acabe por definir como máximos artífices del levantamiento irmandiño ${ }^{143}$.

Esta permeabilidad entre la ciudad y el campo, no difiere mucho de lo que acontecía en el resto de Castilla, donde el medio urbano, carente tanto de una producción industrial importante, como de una actividad comercial a larga distancia, se vio abocado a extenderse a tierras de labrantío, adquiriendo así un contrastado carácter agrario. Esta simbiosis entre el medio urbano y el medio rural, daría lugar a la negación de otorgar por parte de Julio Valdeón, una naturaleza particularmente burguesa a los diferentes conflictos sociales desarrollados a lo largo de la baja Edad Media castellana ${ }^{144}$. Revueltas que aunque de carácter urbano, estarían marcadas por un protagonismo absoluto del campesinado, entre otras razones, debido a la práctica inexistencia de una clara distinción entre ciudadanos y labradores, ya que los rendimientos del desempeño de la artesanía,

139 FERRO, X. (1996). A vida e a fala dos devanceiros. Escolma de documentos en galego dos séculos XIII ao XVI, Vol. II. Vigo: Galaxia, pp. 93 y 139.

140 Ibidem, p. 287.

${ }^{141}$ SÁNCHEZ, Mª.C. El Bajo Miño en, p. 246.

142 DEAÑo, C. A. Rivadavia y, p. 138.

143 Barros, C. Mentalidad justiciera, p. 186.

${ }^{144}$ VALDEÓN, J. Los conflictos sociales, pp. 16-17. 
siempre eran susceptibles de completarse con el trabajo de la tierra ${ }^{145}$. Además, la oligarquía urbana articulada por medio de la más estrecha identificación entre mercaderes y caballeros villanos, lejos de establecer una antítesis frente al poder feudal, se sometería al mismo, en pos de la defensa de un interés común: la obtención de un rendimiento derivado del poder ejercido sobre las clases populares, fuesen éstas del campo o de la ciudad ${ }^{146}$. No es de extrañar, en consecuencia, que los mercaderes burgaleses con el fin de alcanzar cierto prestigio social, imitando usos y costumbres nobiliarias, se embarquen en una política de adquisición de tierras, que les pueda equiparar a la nobleza terrateniente ${ }^{147}$. De esta manera, no sólo se harían con la propiedad de bienes rústicos, sino que no tardarían en constituir sus propios señoríos familiares a semejanza de los tradicionales poderes feudales ${ }^{148}$. Incluso la riqueza del patriciado urbano de Barcelona tuvo su origen, no en el comercio, sino en la administración de bienes inmuebles y en la parcelación del suelo, con lo cual, el supuesto enfrentamiento entre los dos modelos de aristocracia, la específicamente feudo-agraria y la capital-urbana resulta, cuanto menos, muy discutible ${ }^{149}$. De hecho, tanto en la Francia, como en las ciudades flamencas del siglo XVII, las élites urbanas descenderían de antiguos mercaderes, que paulatinamente fueron abandonando el mudable ámbito del comercio marítimo, en aras de la mayor estabilidad que les otorgaba su conversión en propietarios terratenientes ${ }^{150}$. En cuanto a Galicia, aparece documentada, tanto en Orense como en Pontevedra y Santiago, la tendencia cada vez más generalizada, por parte de familias de comerciantes acomodados, relativa en conectar con la hidalguía a través de enlaces matrimoniales, con el fin de emparentarse con linajes nobiliarios ${ }^{151}$. Es esta hidalguía, cuya extracción social estructura los cabildos

145 CARLÉ, C. (1965). “Tensiones y revueltas urbanas en León y Castilla (siglos XIII-XIV)”. Anuario del instituto de investigaciones históricas, 8, pp. 325-356.

146 VALdeÓn, J. (1989). "La corona de Castilla en los siglos XIV y XV. Crisis y transformaciones.”En TuÑón DE LARA, M. (Dir.). Historia de España, Vol. IV. Barcelona: Labor, pp. 93-197.

147 Caunedo Del Potro, B. (1983). “Los negocios de Diego de Soria, mercader burgalés”. Actas del I congreso de historia de Burgos, pp. 163-172.

148 CASADO, H. (1990). “Solidaridades campesinas en Burgos a fines de la Edad Media”. En PASTOR, R. (Comp.). Relaciones de poder, de producción y parentesco en la Edad Media y Moderna. Madrid: CSIC, pp. 279-304.

149 Palos, J.L. (1994). Catalunya a l'imperi dels Austria. Lleida: Pagès Editors, pp. 191-192.

150 MolAs, P. (1992). “La sociedad estamental”. En RIBOT, L. A. (coord.). Historia del mundo moderno. Madrid: Actas, pp. 79-97.

${ }^{151}$ ARmas, J. (1992). Pontevedra en los siglos XII a XV. Configuración y desarrollo de una villa marinera en la Galicia Medieval. Pontevedra: Fundación Pedro Barrié de la Maza, Conde de Fenosa, p. 208 (el autor comenta el ejemplo paradigmático de la familia de los Crúu). 
catedralicios, la que constituye, sin por ello dejar de mantener una estrecha relación con el entorno rural, la oligarquía urbana de las ciudades gallegas. ${ }^{152}$ Sería por tanto coherente afirmar, tal como lo hizo Hilton, que la mayor amenaza contra el orden socioeconómico establecido, lejos de provenir de un patriciado urbano que identificaba parte de su porvenir con el éxito en la adquisición de excedente agrícola, solamente pudo hacerlo del campesinado, único sustento de dicho orden como agente retributivo de la renta feudal ${ }^{153}$. No obstante, esta aristocracia urbana gallega, compuesta de mercaderes e hidalgos, como es obvio, dado lo apetecible de sus rentas, también sería víctima de los agravios señoriales. Plenamente conscientes de la amenaza que para sus intereses, suponía la constante inestabilidad social y económica derivada de los continuos desmanes de la nobleza rural, no tardaron en participar en el movimiento irmandiño, acaparando la dirección política del mismo en su vertiente ciudadana ${ }^{154}$. No sorprende, por lo referido con anterioridad, la escrupulosa observancia por parte de las hermandades urbanas, de las costumbres y leyes inherentes al sistema político feudal de la época. De manera que en primera instancia, conminaron a los diferentes señores para que entregasen sus fortalezas otorgándoles por las mismas una fianza como garantía. Circunstancia, que se constata en el préstamo que concede el concejo de Orense de veinticinco mil pares de blancas a la hermandad de esta localidad, con el fin de cubrir el aval extendido por el castillo Ramiro ${ }^{155}$. Incluso precediendo al derrocamiento, la política urbana se encaminó a intentar preservar las fortalezas, cediéndolas a un caballero afín a la causa, a través de la institución del pleitohomenaje.

...dize este dicho testigo que andando asi la dicha hermandad bio benir un alcalde de la dicha hermandad de la çiudad de Sanctiago que se llamaba Joan Ares Chantrero a su creer a la dicha fortaleza de Rodero que hes de la sancta Iglesia de Santiago e siendo alcalde della un Afonso Crespo, dize este testigo que la entregara al dicho alcalde de Santiago e quel dicho Alcalde la entregara a los alcaldes de la hermandad de la dicha tierra de Canba, los quales la entregaran a Basco Lopez de Cangas y el la resçibiera dellos y les feziera pleitomenaje por ella... ${ }^{156}$

Episodio más significativo de la celebración de esta institución, lo protagoniza el concejo de Orense con la entrega de las llaves de la catedral de la ciudad a un

\footnotetext{
${ }^{152}$ LóPEZ, A. (1999). A cidade medieval galega. Vigo: A nosa terra, pp. 192-200.

153 Hilton, R. Conflicto de clases, pp. 76 y 89.

154 Barros, C. (2006). “Lo que sabemos de los irmandiños”. Clio \&Crimen, 3, pp. 36-48.

${ }^{155}$ Ferro, X. A vida e a fala, Vol. II, pp. 373-374.

${ }^{156}$ RodRíGUEZ, Á. Las fortalezas de, p. 506.
} 
escudero llamado Nuno Dousende, alcalde de la hermandad de dicha localidad, para que pudiese apoderarse enno alto e baixo dela. Como contraprestación, éste tendría que hacer pleito y homenaje. En consecuencia, se puede apreciar el tratamiento de feudo que el concejo otorga a la iglesia, dominio que adquiere el escudero a través del rito del inmixtio manuum, poniendo sus manos entre las de su señor, en este caso el regidor de la ciudad de Orense. El vasallo se compromete, mediante juramento de fidelidad, a hacer la guerra para defender la villa de sus enemigos, a acoger dentro del recinto sacro a los regidores de la ciudad cuando fuese necesario, y a dar e entregar ao dito conçello cada e quando que lle fose demandada ou por seu procurador ${ }^{157}$.

Este acatamiento, por parte de las hermandades urbanas de la legalidad del orden socioeconómico vigente, no tuvo la correspondencia deseada por parte de los irmandiños del medio rural. Circunstancia que se colige de la toma y derribo, sin el consentimiento, pero sí con la censura de los representantes de la hermandad de Orense, de algunas de las fortalezas sitas en la comarca de Ribeiro, y cedidas por dicha agrupación a caballeros adictos, bajo fórmula de pleito-homenaje $\mathrm{e}^{158}$.

Si se ha de incorporar en la naturaleza del movimiento irmandiño, un carácter político de clara connotación antifeudal, más allá del sentimiento meramente antiseñorial derivado del odio y la sed de venganza, frutos del común sufrimiento ante la injusticia originada por los actos de los señores, parece lógico pensar, que éste sería proclive a alcanzar su gestación en el marco de las relaciones de producción propias del medio rural. Así, lo que empezaría siendo un movimiento legítimo y autorizado, cuya primera finalidad sería la de garantizar el orden social, combatiendo a los conculcadores del mismo, terminaría transmutándose, gracias a la actitud de parte del campesinado, en un levantamiento imbuido con las más altas miras vulneradoras del orden socioeconómico establecido. Esta política transgresora, se dirigiría hacia dos líneas de actuación típicamente antifeudales: el impago de la renta señorial y la ocupación de las tierras de los señores. El primer supuesto, queda bien representado en el levantamiento orquestado por los dependientes del monasterio de Sobrado, defendiendo su negativa a pagar la luctuosa a dicho monasterio. Ante tal coyuntura, el catorce de enero de 1469 se reuniría en Orense una junta general de la Santa Hermandad, cuyo objetivo no sería otro que el de deshacer tal agravio, obligando a los campesinos a pagar dicho mal

${ }^{157}$ FERro, X. A vida e a fala, Vol. II, p. 377.

158 Ibidem, pp. 375-376. 
uso y restituir así el sistema señorial de la zona ${ }^{159}$. Estas diligencias, forman parte de una línea política de gobierno, arraigada en las hermandades ciudadanas, por la cual el interés prioritario, no se circunscribiría en abolir los derechos señoriales en su totalidad, sino únicamente aquellos de nueva aplicación, impuestos mediante la fuerza por el señorío laico, y contra las fórmulas jurídicas imperantes, vinculadas al derecho consuetudinario. Se explica de esta manera, que el dos de abril de 1467, el alcalde de la hermandad de Vilanova de Arousa, se reúna con tres de los vecinos más viejos de la villa, y por consiguiente, conocedores de las costumbres y derechos usados en el puerto antaño, con el fin de que ...fiquen cortadas todas las maneras, tratados, usos e costumes que
novamente eran postos...

La segunda directriz asumida por el campesinado, orientada a la damnificación del régimen señorial, la ocupación de los señoríos, se desarrollaría en toda su extensión en tierras de Aguiar. En este territorio los moradores del coto de Melias y Rivela se adueñan de la granja y del coto de San Lorenzo, con su puerto y barca de pasaje de la que pasan a percibir todas las rentas. Estando todas estas posesiones bajo la jurisdicción del monasterio de Oseira, su abad, representado por un procurador, recurre a la hermandad de Orense, cuya sentencia obliga a los vasallos del monasterio a desocupar el señorío eclesiástico, y a la liberación de sus rentas ${ }^{161}$. Resolución que no es aceptada por los labradores, que mediante su incomparecencia, se rebelan y niegan el reconocimiento a la autoridad de dicha junta de hermandad ${ }^{162}$.

No hay que olvidar, el preeminente papel que tuvo el señorío eclesiástico, y dentro del mismo, la relevancia de la expansión monástica, como agente vertebrador de las relaciones de producción típicamente feudales en el campo gallego. También se ha apuntado, a lo largo de este estudio, las resistencias protagonizadas por el campesinado, fruto del conflicto de intereses entre éste, y el señorío monástico al que estaba sujeto.

159 AHN, Sección clero, Códice 341/B, folio 30. Ed. BECEIRO, Isabel. (1977). La rebelión irmandiña. Madrid: Akal, p. 151.

${ }^{160}$ LÓPEZ, A. (1883). Galicia en el último tercio del siglo XV. Santiago de Compostela: Imprenta de La Gaceta, p. 84.

161 AHN, Sección clero, Cárpeta 1554, n 13. Ed. GARCÍA, J. (1977). Galicia en la Baja Edad Media. Iglesia, señorío y nobleza. Santiago de Compostela: Bibliófilos gallegos, pp. 249-251.

162 BARros, C. (1993). "Vivir sin señores. La conciencia antiseñorial en la baja Edad Media gallega”. Señorío y feudalismo en la Península Ibérica, 4, pp. 11-49. 
Sin embargo, en lo relativo a la constitución de las hermandades urbanas, no hay que obviar el destacado papel empeñado por los cabildos catedralicios en la financiación de las mismas. Así, el cabildo de la catedral de Santiago dona en marzo de 1467, 4.000 maravedíes al arca de la hermandad. Algún tiempo más adelante, sería el cabildo de Tuy quien otorgue una ayuda económica para la hermandad de dicha localidad. El soporte de los diferentes cabildos, sobrepasaría el aspecto meramente económico al participar, como lo empezó haciendo el de Orense, de la estructura jurídico-administrativa de la hermandad ${ }^{163}$. Obviamente, estos organismos rectores se encontrarían en una situación muy alejada de las clases campesinas, como para identificarse con la defensa de sus reclamaciones. Por el contrario, sus lazos de solidaridad encontrarían cierta inclinación en favorecer los intereses monásticos. Una predisposición, que daría lugar a la restitución de una granja a la abadesa del monasterio de San Miguel de Bóveda ${ }^{164}$ y de un coto al abad de Celanova ${ }^{165}$, habiendo sido ambas, posesiones usurpadas por el señorío laico por medio de encomiendas forzosas. Incluso en medidas claramente antinobiliarias, como acontecería con la abolición del amádigo, parece ser que esta tendencia encaminada a beneficiar al señorío monástico persiste. Esta institución, típicamente galaico-portuguesa, consistía en la obligación por parte del campesinado de alimentar a los hijos de los hidalgos, a cambio de la supresión de determinadas cargas fiscales. Pero también constituía una perfecta plataforma de ascenso social de la hidalguía, al facilitar la extensión de sus relaciones de vasallaje a través de tal privilegio. El clero territorial, resultaría el principal damnificado por la práctica de esta institución que con el tiempo se convertiría en la fuente más relevante de proliferación del señorío laico, y en consecuencia el más favorecido por su prohibición ${ }^{166}$.

Se puede afirmar, por tanto, que el movimiento irmandiño fue poco homogéneo, al liberar dos tendencias de acción política de naturaleza claramente enfrentadas. Una de ellas, que se podría definir como legalista, nacida de las gestiones de gobierno del sector más privilegiado de villas y ciudades, y orientada tanto a

${ }^{163}$ LÓPEZ, Anselmo. (1992). Os irmandiños. Textos, documentos y bibliografía. Vigo: Edicións A Nosa Terra, pp. 40-41.

${ }^{164}$ AHPO, Clero Regular, San Clodio do Ribeiro, Bóveda e Reza a Vella: sobre diezmos en 1813. Ed. Fernández, A. (2005). O mosteiro feminino de San Miguel de Bóveda na Idade Media. Estudo histórico e colección documental (séculos XII-XV). A Coruña: Toxosoutos, pp. 200-201.

165 AHPO, Sección Clero-pergaminos, Celanova, Carpeta 1. Ed. FERRO, X. A vida e a fala, Vol. I, pp. 147-148.

166 GutiéRREZ, J.I. (1975). "Puntos de aproximación en torno al movimiento hirmandino. (Relaciones entre la Santa Hermandad y la Santa Hermandade)". Actas de la I jornadas de metodología aplicada de las ciencias históricas, Vol. II, pp. 313-322. 
cumplir la ley en lo relativo a los derrocamientos ${ }^{167}$, como a respetar y defender las costumbres inmanentes del orden social, en el que los mencionados grupos gozarían de una posición destacada. La otra, de carácter antifeudal, llevada a término por las clases más populares, integradas en el mundo campesino y menestral, cuyo objetivo prioritario sería la supresión del dominio social y jurisdiccional del señorío gallego, ya fuese éste laico o eclesiástico. Declaración de intenciones, que bajo la fórmula de la transferencia de la propiedad del señor al campesino, no fue exclusiva del territorio gallego, puesto que, también fue compartida por otro movimiento colectivo campesino de gran alcance durante este mismo periodo, aunque situado en el otro extremo de la península: la segunda insurrección remensa protagonizada por Joan Salas y los labradores de la montaña gerundense ${ }^{168}$.

\section{CONCLUSIÓN}

Los diferentes atropellos y desmanes provocados por una ávida nobleza laica, fueron el detonante, en primera instancia, de un levantamiento generalizado en la sociedad gallega mediante la constitución de hermandades. Sin embargo, no hay que olvidar que este estallido de violencia, no fue más que el epígono de siglos de resistencias latentes por parte del campesinado contra el señorío territorial y jurisdiccional imperante en el medio rural gallego. La actuación por parte de los señores, para responder a la crisis del siglo XIV, no haría más que acentuar en la mentalidad popular, la quiebra del modelo teorético trifuncional. Así, el campesinado unido por una conciencia colectiva frente al agravio de los señores, y constituido plenamente como clase social, eso sí, sujeta a grandes diferenciaciones socioeconómicas internas, se articularía como primer agente trasgresor del régimen señorial imperante, bajo el amparo del movimiento irmandiño. Esta línea de actuación, transcendería la primigenia instancia de rechazo, fermentado por el odio, ante la perspectiva de asumir una situación insoportable provocada por las vejaciones del señorío laico ejercidas desde sus fortalezas, y se orientaría hacia una tentativa de desarticular todo tipo de régimen señorial, en especial, dadas las características del agro gallego, el ejercido por los rectores monásticos. Actitud ésta ni mucho menos secundada por las clases rectoras del entorno urbano, afines a preservar las costumbres inherentes del orden socioeconómico existente, y por

${ }^{167}$ El asalto de las fortalezas, tendría una base legal en la cuarta disposición del Reglamento de la Hermandad de Concejos gallegos y castellanos, reunida en Valladolid que establecía que si un ladrón se acogía en casa de un noble, le fuesen a éste confiscados bienes por el valor de lo robado y si esto no se cumplía que se derribase la fortaleza donde se amparaba. PORTELA, S. (1957). Galicia en el tiempo de los Fonsecas. Madrid: C.S.I.C, p. 48.

${ }^{168}$ VICENS I VIVES, J. (1954). Notícia de Catalunya. Barcelona: Àncora, p. 52. 
tanto, alejadas de las demandas campesinas. En consecuencia, se puede llegar a afirmar la existencia de un movimiento irmandiño, acreedor de una heterogeneidad nacida de intereses enfrentados en el seno de la sociedad gallega. Aquellos relativos a un campesinado, convertido en la mayor amenaza del orden socioeconómico existente y los referentes a una oligarquía urbana, partícipe en posiciones destacadas del mismo, y solamente vinculada al conflicto antiseñorial en aras de una actitud legalista, inmanente de la defensa del orden público. 
